\title{
IMMUNOHISTOCHEMICAL STUDY OF SUBSTANCE P NERVES IN THE RETICULUM OF CATTLE WITH SPECIAL REFERENCE TO PROBABLE SENSORY RECEPTORS IN THE MUCOSA
}

\author{
N. Kitamura, J. Yamada and T. Yamashita \\ Department of Veterinary Anatomy, Obihiro University of Agriculture and \\ Veterinary Medicine, Obihiro, Hokkaido 080, Japan
}

\section{Introduction}

The presence of sensory receptors in the reticulum wall has been reported physiologically and neural elements are considered to play this sensory role (Leek and Harding, 1975). However, no information is available on the nature of these nerves or the substances contained in them. The presence of sensory neuron containing substance $P$ in the enteric neural circuit has been suggested (Sundler et al., 1980). Although we reported the presence of substance $P$ nerves in the bovine reticulum (Kitamura et al., 1986), those data present fragmentary information on the mucosa due to utilizing thin paraffin sections.

Present study reports the architecture of substance $P$ nerves in the reticulum with special reference to the papillae using thick sections from cattle treated with colchicine in order to enhance the immunoreactivity.

\section{Materials and Methods}

Reticulum tissues were obtained from Holstein calves (10- and 15-day-old) and cow pretreated with colchicine $(5 \mathrm{mg} / \mathrm{kg}$, intraperitoneally). Untreated cow was also used. Tissues were fixed with a mixture of picric acid and formalin or Bouin's fluid. After washing with $70 \%$ alcohol and phosphate buffered saline, the tissues were embedded in $30 \%$ gelatin and sectioned at $100 \mu \mathrm{m}$ using Microslicer (Dosaka, Kyoto). These sections were degelatinized and then stained immunohistochemically using anti-substance P monoclonal antibody (Sera-lab, Sussex, NCl/34HL, 1:1000), biotinylated anti-rat IgG antibody (Vector, Burlingame, 1:400) and Vectastain Elite ABC kit (Vector, 1:4).

\section{Results and Discussion}

Colchicine pretreatment enhanced the immuno- reactivity for not only nerve cell bodies but also nerve fibers. Abundant substance P-immunoreactive nerve fibers were detected in the external muscle layer and in the smooth muscle bundle in the reticular folds. Myenteric ganglia contained numerous substance P-immunoreactive nerve cell bodies and moderate number of nerve fibers. Substance P-immunoreactive nerve cell bodies frequently showed peripheral arrangement in the ganglia. Numerous perivascular nerve fibers showed substance P-immunoreactivity.

In the mucosa, substance P-immunoractive nerve cell bodies were detected near the epithelium. These nerve cell bodies were predominantly located in the floor of the reticular cells and seemed to be more numerous in calf than in cow. Subepithelial nerve cell bodies were present solely and sometimes in cluster consisting of several cells. The process of these cells were frequently visible. Occasional nerve cell bodies were detected in the smooth muscle bundle in the reticular folds.

Substance P-immunoreactive nerve fibers were detected predominantly near the epithelium. Several nerve fibers were passing up the core of each papilla, particularly in the conical papillae. These fibers branched many times and convoluted, showing appearance like a glomerulus or floccule in the tip of the papillae (figure 1A). These complicated architecture were detected mainly in the tip of conical papillae, although they were sometimes detected also in the papillae on the sides of the reticular folds (figure 1B). Subepithelial nerve fibers followed a tortuous pathway but they were unlikely to penetrate into the epithelium.

Most striking feature in the present study is the presence of the complicated architecture of substance $\mathrm{P}$-immunoreactive nerve fibers in the tip of the papillae. These structures are supposed to play a role as sensory receptors based on the locations, appearance and containing substance $\mathrm{P}, \mathrm{a}$ putative sensory neurotransmitter. Whether these 

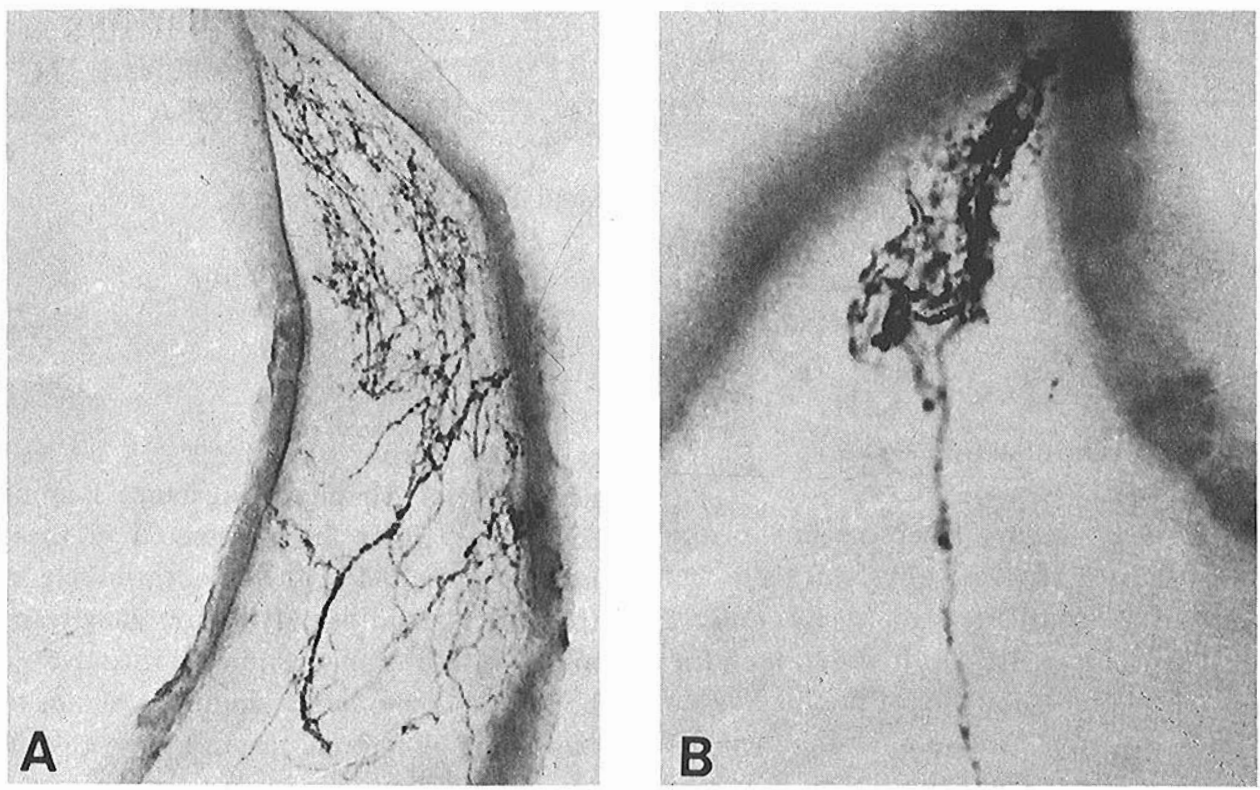

Figure 1. Substance P-immunoreactive nerve fibers in the conical papilla (A) and the papilla on the side of the reticular fold $(B)$ of the reticulum from colchicine treated cow. $A \times 60$, B $\times 150$.

neural structures participate in the intramural reflex or the extrinsic reflex, or both should be clarified.

(Key Words: Substance P, Immunohistochemistry, Reticulum)

\section{Literature Cited}

Kitamura, N., J. Yamada and T. Yamashita. 1986. Immunohistochemical study on the distribution of neuron-specific enolase- and peptidecontaining nerves in the reticulo-rumen and the reticular groove of cattle. J. Comp. Neurol. 248:223-234.

Leek, B.F. and R.H. Harding. 1975. Sensory nervous receptors in the ruminant stomach and the reflex control of reticulo-ruminal motility. In "Digestion and Metabolism in the Ruminant" (Ed. by I.W.M. McDonald and A.C.I. Warner) University of New England Publishing Unit, pp.60-76.

Sundler, F., R. Hakanson and S. Leander. 1980. Peptidergic nervous systems in the gut. Clin. Gastroenterol. 9:517-543. 